\title{
Medical Applications of New Electroactive Polymer Artificial Muscles
}

\author{
Roy Kornbluh* $\cdot$ John Bashkin* $\cdot$ Ron Pelrine* $\cdot$ Harsha Prahlad* $\cdot$ Seiki Chiba*
}

Electroactive polymer artificial muscles are an emerging class of transducers with properties not found in existing actuators, generators, or sensors. A particularly promising class of electroactive polymers is dielectric elastomers. Dielectric elastomers are based on the electromechanical response of a rubbery material located between compliant electrodes. Properties of dielectric elastomers that are relevant for medical applications include softness similar to biological tissue, actuation stroke and force similar to biological muscle, use of biocompatible materials, high energy efficiency, the ability to form arrays on a single substrate, and extremely low material costs. These properties may be exploited for a variety of medical applications both in devices for the human body such as prosthetics, assistives, or diagnostics as well as devices for diagnosis and medical research in laboratories or clinics. Specific examples of dielectric elastomer devices under development include artificial muscles for prosthetic limbs, soft skins for haptic stimulation and sensing, disposable microfulidic devices with embedded pumps and valves, and prosthetic and orthotic organ devices such as artificial diaphragm and heart assist devices, to name but a few. Some lifetime and packaging issues remain, but we expect to see devices based on electroactive polymer artificial muscles with new capabilities in medicine within the next few years.

エレクトロアクティブ高分子型人工筋肉は, 今までのア クチュエータや発電装置, センサー等には無い特性を有し た新しいタイプの変換器である. エレクトロアクティブ高 分子の中で特に実用化の可能性が高いのは, 誘電エラスト マーである．駆動原理は，エラストマーの上下に柔軟性を 有した電極で挟み通電することにより生じるマクスウェル 応力にて，エラストマーを厚さ方向に押し付け，その結果 面積を広げ，伸ばすことが可能となる．色々な高分子がこ れまで試されたが, NuSil Silicon Technology 社のシリコ ンゴムをベースにしたものと $3 \mathrm{M}$ 社のアクリルをベース

\footnotetext{
* SRI International,

333 Ravenswood Avenue, Menlo Park CA 94025

(Seiki Chiba E-mail : schiba@sri.co.jp)

Received Sep.28, 2004.
}

にしたエラストマーが最高の性能を得ている．これらの人 工筋肉は，スピンコーティング，ディップコーティング， キャスト，スプレーなどの良く知られた技術を用いて製作 される ${ }^{11}$.

誘電エラストマーを用いた人工筋肉は，硬さが生物の組 織に近く，駆動力や伸びが生物の筋肉に匹敵し，形を思い 通りに成形することが可能で，コストがとても安く，かつ 効率がとても高いため, 義手・義足，実際に人間の体を診 断するデバイスや医療研究用デバイス等のアプリケーショ ンに向いている. 現在, 研究・開発している例を挙げると, 義足・義手，ハプテッイクやセンシングが可能な柔らかい 皮膚, 血液等を診断するマイクロ流体システム用のポン プ・バルブや使い捨ての埋め込み型ポンプ・バルブ，人工 器官（例，人工横隔膜や心臓の鼓動を補助する装置等）な どである. 実用化されるには，パッケージングの研究や各 種の試験等が必要であるが, 近い将来エレクトロアクティ ブ高分子型人工筋肉を利用した新しい特性を有した医療機 器が実現すると思われる。

\section{Introduction: Polymers for the Body and Benchtop}

Electroactive polymers (EAPs), often called "artificial muscles," are an emerging class of transducers that are being developed for applications requiring actuators, generators, sensors, or smart skins that combine these transducer functions with other functions such as structural support or protection. EAPs differ greatly in type of materials, physical design, and performance from existing transducers such as electromagnetics, piezoelectric ceramics, or shape-memory alloys, to name but a few. These differences include many properties that can be effectively exploited to enable improved medical devices as well as open up a range of new possible devices.

The most striking difference between EAPs and existing technologies is that EAPs are made from polymer materials that are much softer than the hard metallic or ceramic materials used in other transducers. These polymer materials bear greater resemblance to the soft tissues found in the human body and thus can be wellsuited to implantable devices or devices that must interface with the body. Beyond this commonality of softness, 
Table 1 Properties of dielectric elastomer EAP and medical relevance

\begin{tabular}{l|l}
\hline \multicolumn{1}{c|}{ Property } & \multicolumn{1}{c}{ Medical importance } \\
\hline Soft & Will not damage tissue, comfortable, mechanically couples to tissue \\
\hline High strains & Simple device with few moving parts, no lubrication \\
\hline High energy density and power efficiency & Lightweight and compact device, no heat generation \\
\hline Stroke and force akin to natural muscle & Replaces muscle for prosthetic or orthotic devices \\
\hline Biocompatible materials & Implantable or can allow for prolonged contact with the body \\
\hline Quiet & More comfortable for patients when used in or on the body \\
\hline Ability to form arrays on a single substrate & Parallel devices, smart “skins" for sensing or stimulation \\
\hline Extremely low material costs & Affordable, disposable \\
\hline Good environmental tolerance & Can survive sterilization, outdoor use, long lifetime \\
\hline No metallic parts & Suitable for use in MRI machines, X-ray transparency \\
\hline
\end{tabular}

In the following section we describe the basic operation and properties of dielectric elastomers ; next we present specific examples of the types of transducers for medical applications and describe how each exploits the properties presented above.
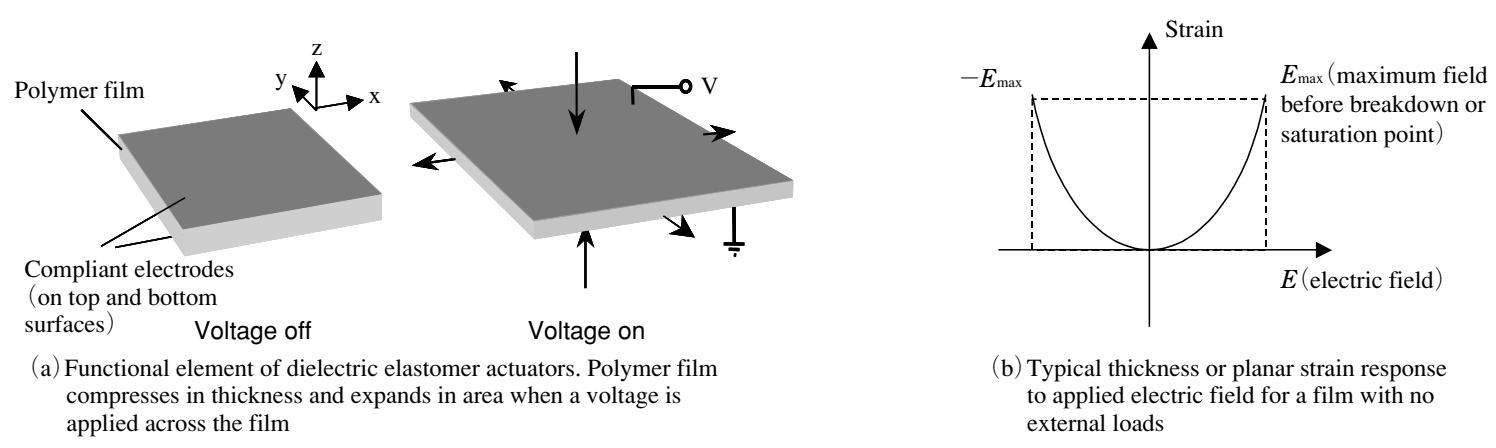

(b) Typical thickness or planar strain response to applied electric field for a film with no external loads

Fig. 1 Principle of operation of dielectric elastomer actuators

there are a variety of types of EAPs, each with its own potential benefits and limitations. A review of the types of EAPs can be found in References ${ }^{2)}$. . Rather than exhaustively consider each type of EAP and its potential applications, we will focus in more detail on the type of EAP developed by the authors-dielectric elastomers.

Dielectric elastomers were pioneered by the authors and others at SRI International, but several research groups around the world are now actively investigating applications of this technology [e.g, 5) - 7)].

Properties of dielectric elastomers that can be exploited for medical applications are presented in Table 1.

In the following section we describe the basic operation and properties of dielectric elastomers; next we present specific examples of the types of transducers for medical applications and describe how each exploits the properties presented above.

\section{Basic Principles and Properties of Dielectric Elastomer EAPs}

Dielectric elastomer transducers are based on the electromechanical response of an elastomeric dielectric film with compliant electrodes on each surface. These transducers may be actuators, generators, or sensors. Actuators based on dielectric elastomer technology operate on the simple principle shown in Fig. 1. When a voltage is applied across the compliant electrodes, the polymer shrinks in thickness and expands in area.

The net volume change of the polymer materials that we investigated is small because of their high bulk moduli. Therefore, the electrodes must be compliant to allow the film to strain. The observed response of the film is caused primarily by the interaction between the electrostatic charges on the electrodes ${ }^{9)}$ : The opposite charges on the two electrodes attract each other, while the like charges within each electrode repel each other. Using this simple electrostatic model, we can derive the effective pressure produced by the electrodes on the film as a function of the applied voltage ${ }^{10)}$. The pressure, $p$, is given by $p=\varepsilon_{\mathrm{r}} \varepsilon_{\mathrm{o}} E^{2}=\varepsilon_{\mathrm{r}} \varepsilon_{\mathrm{o}}(V / t)^{2}$, where $\varepsilon_{\mathrm{r}}$ and $\varepsilon_{\mathrm{o}}$ are the permittivity of free space and the relative permittivity (dielectric contact) of the polymer, respectively; $E$ is the applied electric field; $V$ is the applied voltage; and $t$ is the film thickness. The response of the polymer is functionally similar to that of electrostrictive polymers, in that the response is directly related to the square of the applied electric field.

Many polymer materials can function as dielectric elastomer actuators, so, unlike most other electroactive polymers, different polymer materials can be selected for dif- 


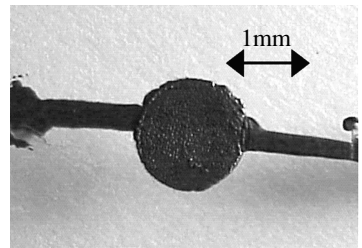

Voltage off

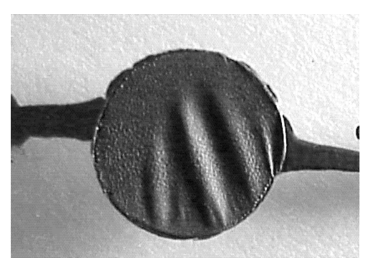

Voltage on

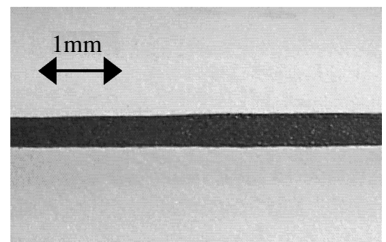

Voltage off

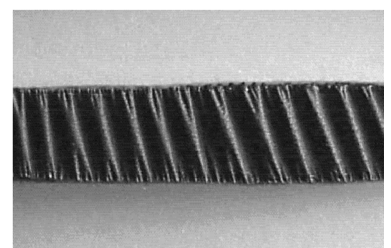

Voltage on

Biaxially prestrained film

Uniaxially prestrained film

Fig. 2 Acrylic elastomer undergoing large actuation strain as indicated by the expansion of the electrodes (dark areas)

Table 2 Properties of best silicones and acrylics

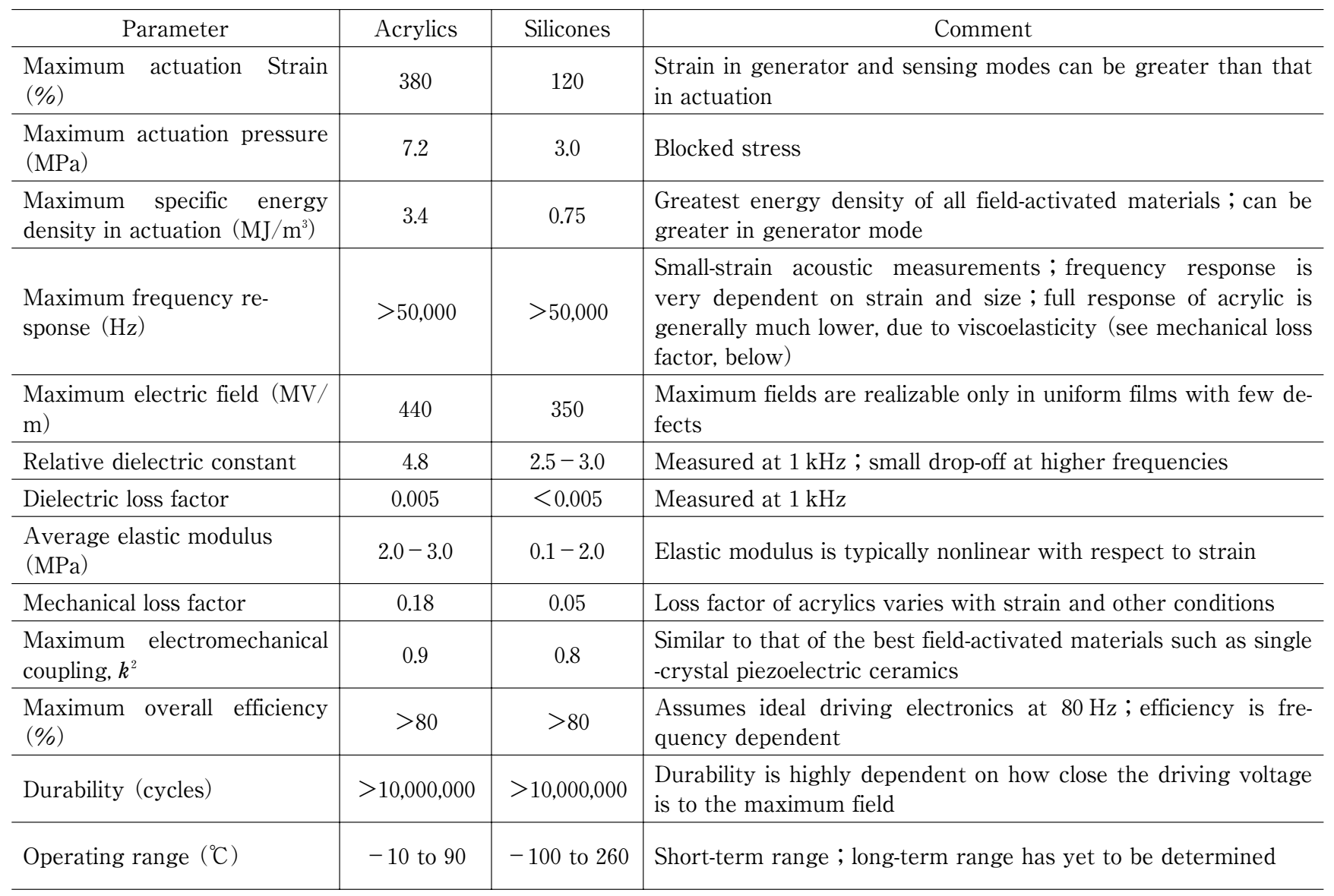

ferent applications, depending on the desired performance and physical properties. The best-performing materials (those with greatest strains) are based on commercially available formulations of silicone rubber (polydimethyl siloxane) and acrylic elastomers.

Both silicone and acrylic materials have produced more than $100 \%$ actuated strain. Fig. 2 shows the large strains (more than 200\%) that acrylic can achieve. The specific energy density associated with such large deformations is greater than that produced by any other fieldinduced actuator technology ${ }^{11)}$. Because the pressure response is due to the electrostatic charges (electric field activated), it is very rapid. The strain response is limited in speed by the damping of the polymer and the modal frequencies that result from the elasticity of the polymer and the driven inertia. For large strains $(>10 \%)$ sili- cones have shown response frequency bandwidths of more than $1 \mathrm{kHz}$, while acrylics have exhibited bandwidths of more than $100 \mathrm{~Hz}$.

Table 2 summarizes the relevant properties and performance of the best acrylic and silicone materials. More details are given by Kornbluh et al. ${ }^{12}$.

The same transducer structure can serve as an actuator, generator, or sensor, depending on how it is electrically driven. The operation of dielectric elastomers as generators is discussed in more detail by Pelrine et al. ${ }^{13)}$.

In the actuator mode, the dielectric elastomers apply a mechanical pressure in response to an applied electric field. The reverse of this process can also yield a sensor. In this mode of operation, an applied pressure on the polymer film results in a change in capacitance between the compliant electrodes of the film. The change in ca- 

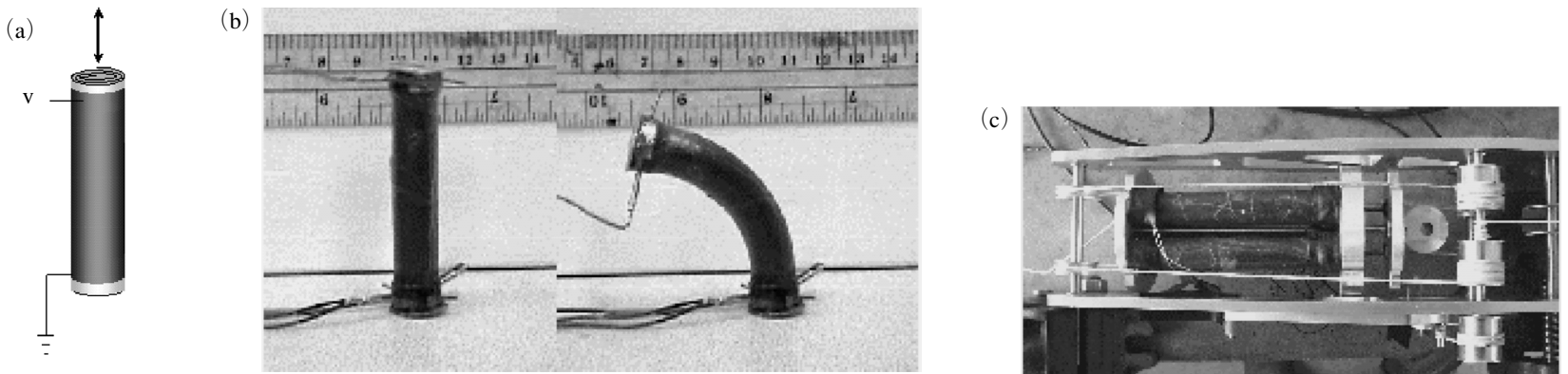

(d)
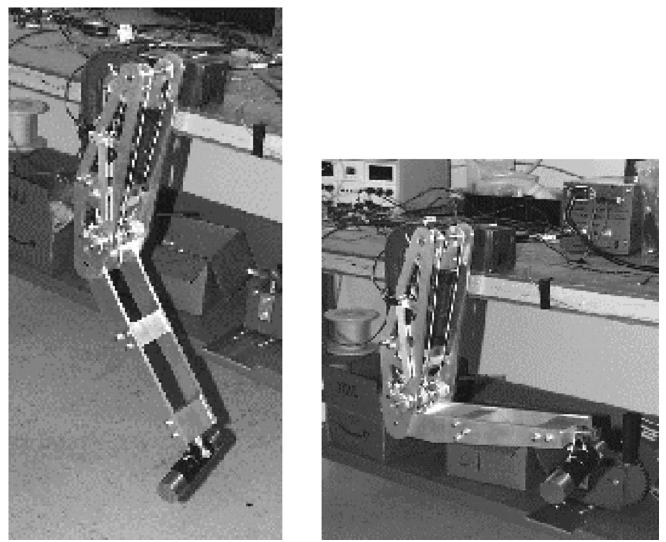

Fig. 3 Rolled actuator artificial muscles: (a) basic roll structure, (b) bending roll approximately $7 \mathrm{~cm}$ long, (c) a bundle of artificial muscles installed in a prototype of a prosthetic arm (each muscle is about $10 \mathrm{~cm}$ long), (d) the artificial muscle powered arm shown lifting a weight. (Photos (c) and (d) courtesy of ADA Technologies, Inc..)

pacitance is due to both the increase in planar area and a decrease in film thickness, and can be measured directly to determine the applied pressure. Since the polymer materials can be very soft in nature, they add minimum stiffness to the overall structures when used as a sensor. In addition, since the electric impedance and the output of a dielectric elastomer transducer are related to the deformation of the polymer film, it follows that these transducers could also be used to detect strain at the same time as performing actuation or generation. For example, the capacitance of a linear actuator could be directly related to the amount of its linear motion.

The basic element shown in Fig. 1 can be incorporated into a wide variety of transducer configurations. For example, the film and electrodes can be formed into a tube, rolled into a scroll, supported by a frame, or laminated to a flexible substrate to produce bending. Which configuration is best depends on the application and properties of the film. In some cases, such as bending beam actuators (unimorphs and bimorphs), the film can be laminated directly to a structure whose shape or dynamics we want to control. The resulting composite may be considered to be a "smart structure" ${ }^{14)}$.

\section{Examples of Transducers and Medical Applications}

The great diversity of form and function of dielectric elastomers suggests that a wide range of medical applications can be addressed. Here we present several transducer types and discuss their medical application.

\section{Rolled Actuators for Artificial Muscles}

Rolled actuators incorporate a large amount of active polymer film into a compact shape. In fact, the tubular shape approximates the tubular shape of many biological muscles. In addition to being simple linear actuators, the rolls can also be made to bend by selectively actuating different regions of electrodes. Fig. 3 shows several rolled actuators that have medical application. For example, the bending roll could be the basis of thin and dexterous laproscopic surgical tools, steerable or selfpropelled colonoscopes, or catheters. A bundle of artificial muscles (analogous to muscle fibers) was installed in a prototype of a prosthetic arm to show how the musclelike behavior could result in a prosthetic limb that is compact, lightweight, quiet, responsive to contact with objects, and energy efficient (the arm itself was built by ADA Technologies, Inc., Littleton, Colorado, USA).

\section{Diaphragm Actuators for Pumps}

Diaphragm actuators (Fig. 4), consisting of a stretched film layer (or layers) over an opening in a relatively rigid substrate, can form the basis of extremely simple pumps. The large strains of dielectric elastomers permit strokes that are significantly larger than those produced with other types of diaphragms, such as piezoelectrically driven diaphragms. Typically, silicone dielectric elastomers achieve displacements of $10 \%$ of the diaphragm diameters, while acrylic elastomers could easily achieve displacements of $50 \%$ of their diaphragm diameters. These acrylic elastomers can actuate from an essentially flat configuration to one that is hemispherical. The large volume displacements per stroke of electroactive poly- 


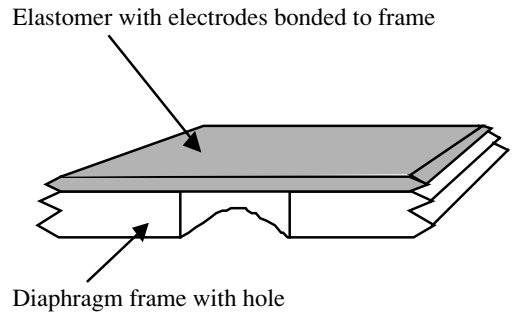

(a) Voltage off

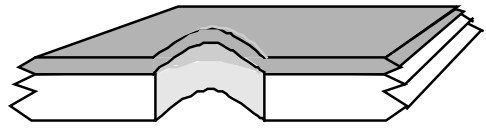

(b) Voltage on

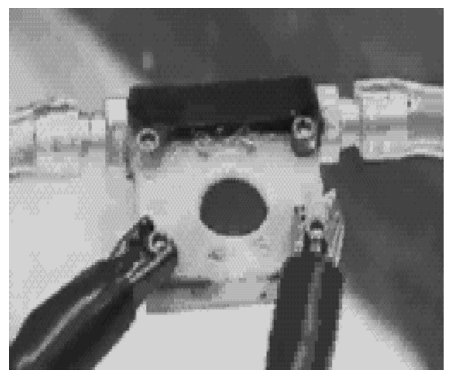

Fig. 4 Diaphragm actuators for pumps : (a) basic structure, (b) acrylic diaphragm incorporated into a low-profile pump for liquids (pump diameter is approximately $\mathbf{1 ~ c m}$ )

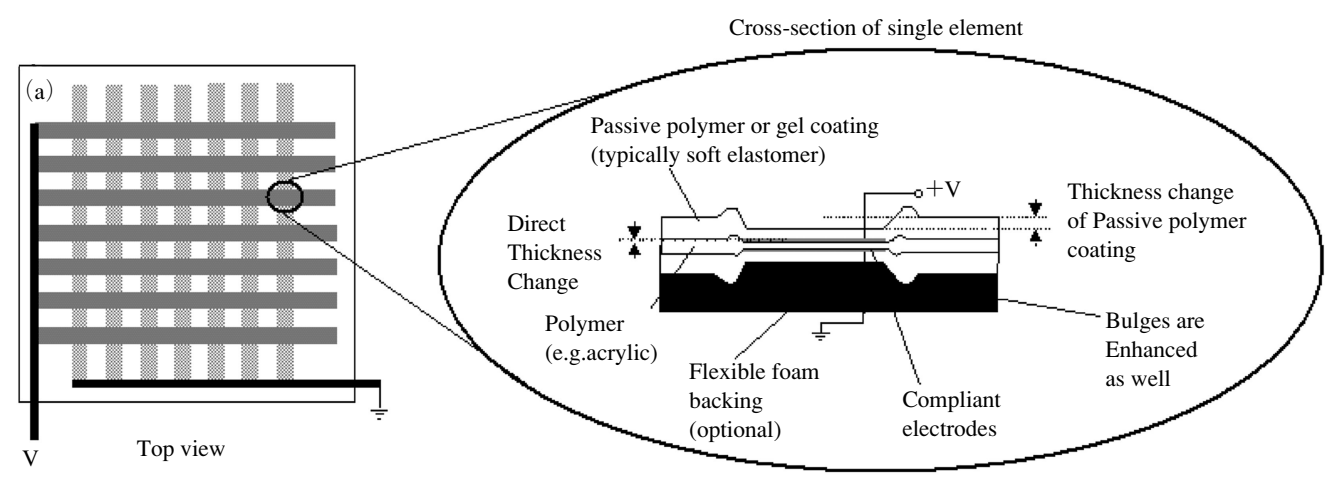

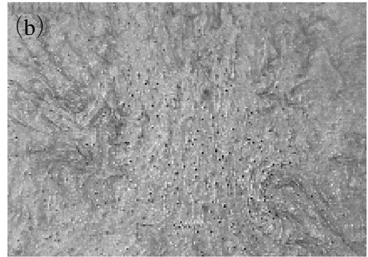

Voltage off

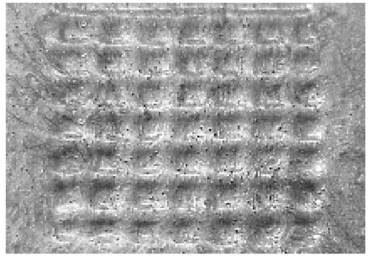

Voltage on

Fig. 5 Enhanced-thickness-mode actuation : (a) underlying electrode grid pattern and schematic of basic element, (b) resulting surface change in silicone gel on top of acrylic dielectric elastomer, with electrodes in grid pattern (each block of the grid is about $1 \mathrm{~cm} \times 1 \mathrm{~cm}$ )

mer actuators make them tolerant of greater leakage and backflow losses in the valves. Passive flapper valves can be used, simplifying the pump design. These simple dielectric elastomer pumps may be well suited for small implantable pumps, such as for drug infusion applications, that require a compact energy-efficient design and quiet operation. The biocompatibility of dielectric materials, such as silicone, is important for implantable devices. We have demonstrated a wide range of diaphragm actuators as small as $50 \mu \mathrm{m}$ in diameter and diaphragm actuators fabricated by spin coating silicone onto a silicon wafer. Pumping pressures as high as $20 \mathrm{kPa}$ have been demonstrated in millimeter-scale diaphragms. We demonstrated the potential of the diaphragm actuator for micropump applications by building a simple proof-of-principle minipump. The $20 \mathrm{~mm}$ diaphragm could pump as much as $40 \mathrm{ml} / \mathrm{min}$ of air at pressures of about $1 \mathrm{kPa}$. Theoretical calculations indicate that much higher diaphragm pressures, around $1 \mathrm{MPa}$, should be feasible.

\section{Enhanced Thickness Mode Actuator Arrays}

A promising actuator configuration for microfluidics as well as several smart skin applications is the enhancedthickness-mode actuator, as shown in Fig. 5. In the enhanced-thickness-mode actuator, a relatively thick passive layer is deposited on top of the active dielectric elastomer. This layer thins or thickens as the layer below it expands or contracts. If the layer is soft enough, the thickness strain is identical to that of the underlying dielectric layer. Since the passive layer is much thicker than the dielectric layer, the absolute change in thickness is large. It is possible to create virtually any desired pattern of bumps and troughs on a single substrate by simply patterning the electrodes on one surface of the dielectric elastomer. The entire structure can be attached to a rigid frame. Alternatively, the structure can be laminated to a flexible foam or gel backing. In this way, a thin flexible skin can be made that can cover large or small areas and contain finely patterned electrodes. This skin could be quite rugged because it is made entirely 
out of rubbery materials. Although the device gives outof-plane motion, it can be fabricated with only twodimensional patterning.

There are several possible medical applications for enhanced-thickness-mode actuation. If an enhancedthickness-mode structure is brought into close proximity with a rigid layer, the bumps and troughs could act as valves or pumping elements in a "lab-on-a-chip" type of microfluidic system. The all-elastomer pad conforms comfortably to the body. This pad can have a massaging or sensory augmentation function. The dielectric elastomer elements of the pad can also be used as sensors to make a touch-sensitive skin for recording human interaction with the environment.

Microfluidic devices promise to enable the rapid screening of pharmaceuticals or allow researchers to better understand the roles of proteins and genes by allowing fast, massively parallel testing. Recently, the need to rapidly screen for disease-causing agents has received much interest. Because the dielectric elastomer device is based on very simple two-dimensional fabrication procedures and uses low-cost materials, it can be made inexpensively enough to be disposable.

\section{Sensors}

We have already noted that dielectric elastomer actuators are also intrinsically position or strain sensors. Dielectric elastomer sensors have certain advantages in their own right, even if the actuation function is not included. The large strain capabilities and environmental tolerance of dielectric elastomer materials allow for sensors that are very simple and robust. In sensor mode, it is not often important to maximize the energy density of the sensor materials since relatively small amounts of energy are converted. Thus, the selection of dielectric materials can be based on criteria such as biocompatibility, maximum strain, environmental survivability, and even cost. As sensors, dielectric elastomers can be used in all of the same configurations as actuators, as well as others. Fig. 6 shows examples of several dielectric elastomer sensors, which can be thin tubes, flat strips, arrays of diaphragms, or large-area sheets. In many applications these sensors can replace bulkier and more costly devices such as potentiometers and encoders. In fiber or ribbon form, a dielectric elastomer sensor can be woven into textiles and provide position feedback from human motion. Such sensors have been shown to be capable of measuring respiration, replacing bulkier pressure sensing chest bands. The use of such strain sensors has also been explored for measuring the expansion of arteries in animal models. These simple one-piece sensors can be made very small and thin. They can replace saline- or mercury-filled tubes that are commonly used by physiologists to measure the expansion of body parts. Dielectric elastomer sensors can also be laminated to structures or skins to provide posi-

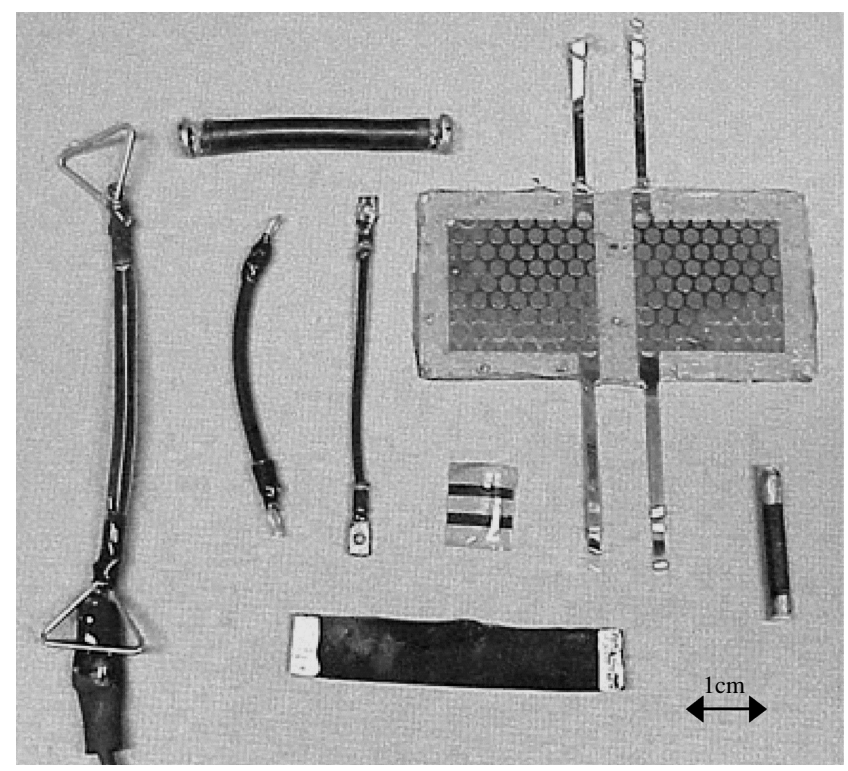

Fig. 6 Representative dielectric elastomer sensors (adapted from 15))

tion information for multifunctional smart materials. Sensors such as the diaphragm array can be used to measure force or pressure as well as motion. We have already noted that enhanced thickness mode pads can act as sensory skins.

\section{Concluding Remarks}

EAPs in general and dielectric elastomers in particular can be expected to make a big impact in medical devices in the near future. It is important to note that thus far all demonstrations have been done at the proof-of-principle stage. Many technical challenges remain for practical implementation. One important issue for dielectric elastomers in medical applications is that they operate at relatively high voltages. Electronics for driving the relatively high voltages of dielectric elastomers, though readily feasible, are not commercially available in many cases and must be developed. In some applications, the cost of converting from available battery or bus voltage will offset the advantages of using dielectric elastomer technology from a cost or size and mass perspective. Other EAPs, such as electrochemical EAPs that operate at low voltage, may be better suited for some applications that do not demand high speed of response, environmental tolerance, or efficiency. While high voltage is often thought of as a safety issue, safety need not be threatened by small devices, even if they operate at very high voltages, because the total current and power required by small devices is minimal-often well below even $0.1 \mathrm{~mA}$, the generally accepted threshold for human perception. An actuator that operates at $1000 \mathrm{~V}$ on this current could still deliver $0.1 \mathrm{~W}$ of energy, a significant amount for a small device, without any risk of shock. Low current, combined with proper insulation should allow dielectric elastomers to be implanted in the body-the most demanding situ- 
ation. Reliability and lifetime are other technical challenges. Properly designed dielectric elastomer transducers have demonstrated long lifetimes (millions of cycles or more) provided they are not driven too close to their maximum voltage limits. However, many life-critical medical applications can require as much as a billion cycles and demand complete reliability. We do not see any fundamental limitations to achieving this lifetime and reliability but further development is required.

More information on dielectric elastomer EAPs, including videos of several EAP devices may be found at www. sri.com/artificialmuscles.

\section{Acknowledgments}

The authors would like to thank the many individuals at SRI International who have contributed to the development of the dielectric elastomer actuation technology. The authors would also like to thank Dr. Qibing Pei of the Universiy of California at Los Angeles and Mr. Bradley Veatch and others of ADA Technolgies, Inc. for contributing to some of the work presented herein. Much of the basic dielectric elastomer technology was developed under the management of the Micromachine Center of Japan under the Industrial Science and Technology Frontier Program, Research and Development of Micromachine Technology of MITI (now known as METI), Japan, supported by the New Energy and Industrial Technology Development Organization. The Defense Advanced Research Projects Agency (DARPA), the Office of Naval Research (ONR), and the National Institutes for Health also sponsored development leading to some of the results presented herein.

\section{REFERENCES}

1 ）千葉正毅:エレクトロニクス実装技術, 18(1), 32(2002)

2 ) Sommer-Larsen, P., and Kornbluh, R.: Polymer Actuators. Proc. Actuator 2002, $8^{\text {th }}$ International Conf. on New Actuators, Bremen, Germany (June), pp. 371-378 (2002)

3 ) Bar-Cohen, Y., (ed.).: Electroactive Polymer (EAP) Actuators as Artificial Muscles-Reality, Potential and Challenges, Second Edition. SPIE Press, Bellingham, Washington (2004)

4 ) Madden, J.: Properties of Electroactive Polymer Actuators. Proc. Actuator 2004, $9^{\text {th }}$ International Conference on New Actuators, 14-16 June, Bremen, Germany, pp. 338-343 (2004)

5 ) Wingert, A., Lichter, M., Dubowsky, S. and Hafez, M. : Hyper-redundant Robot Manipulators Actuated by Optimized Binary Dielectric Polymers. Smart Structures and Materials 2002: Electroactive Polymer Actuators and Devices (EAPAD), ed. Y. BarCohen, Proc. SPIE. 4695 (2002)

6 ) Sommer-Larsen, P., Hooker, J., Kofod, G., West, K.,
Benslimane, M. and Gravesen, P. : Response of Dielectric Elastomer Actuators. Smart Structures and Materials 2001: Electroactive Polymer Actuators and Devices, Yoseph Bar-Cohen, ed. Proc. SPIE 4329, pp. 157-163 (2001)

7 ) Jeon, J., Park, K., An, S., Nam, J., Choi, H., Kim, H., Bae, S and Tak, Y.: Electrostrictive Polymer Actuators and Their Control Systems. Smart Structures and Materials 2001:Electroactive Polymer Actuators and Devices, Yoseph Bar-Cohen, ed.. Proc. SPIE 4329 pp. $380-388$ (2001)

8 ) Kornbluh, R., Full, R., Meijer, K., Pelrine, R. and Shastri. S. : Engineering a Muscle: An Approach to Artificial Muscle Based on Field-Activated Electroactive Polymers. Neurotechnology for Biomimetric Robots. J. Ayers, J. Davis, and A. Rudolph, eds. MIT Press, pp. 137-172 (2002)

9 ) Pelrine, R., Kornbluh, R. and Kofod. G. : High-Strain Actuator Materials Based on Dielectric Elastomers. Advanced Materials 2000 12:16, pp. 1223-1225 (2000)

10) Pelrine, R., Kornbluh, R., Joseph, J. and Marlow, J. : Analysis of the Electrostriction of Polymer Dielectrics with Compliant Electrodes as a Means of Actuation. Sensors and Actuators A : Physical 64, pp. 77 -85 (1998)

11) Pelrine, R., Kornbluh, R., Pei, Q. and Joseph, J. : HighSpeed Electrically Actuated Elastomers with Over 100\% Strain. Science 287 : 5454, pp. 836-839 (2000)

12) Kornbluh, R., Pelrine, R., Pei, Q., Oh, S. and Joseph, J. : Ultrahigh Strain Response of Field-Actuated Elastomeric Polymers. Proc. SPIE, Smart Structures and Materials 2000: Electroactive Polymer Actuators and Devices (EAPAD), Y. Bar-Cohen, ed., Proc. SPIE 3987, pp. 51-64 (2000)

13) Pelrine, R., Kornbluh, R., Eckerle, J., Jeuck, P., Oh, S., Pei, Q. and Stanford, S. : Dielectric Elastomers: Generator Mode Fundamentals and Applications. In Smart Structures and Materials 2001 : Electroactive Polymer Actuators and Devices. Y. Bar-Cohen, ed. Proc. SPIE 4329, pp. 148-156 (2001)

14) Kornbluh, R., Pelrine, R., Joseph, J., Heydt, R., Pei, Q. and Chiba, S.:High-Field Electrostriction of Elastomeric Polymer Dielectrics for Actuation. Smart Structures and Materials 1999 : Electroactive Polymer Actuators and Devices. Y. Bar-Cohen, ed. Proc. SPIE 3669, pp. 149-161 (1999)

15) Kornbluh, R., Pelrine, R., Pei, Q., Heydt, R., Stanford, S., Oh, S. and Eckerle. J. : Electroelastomers : Applications of Dielectric Elastomer Transducers for Actuation, Generation and Smart Structures. Smart Structures and Materials 2002 : Industrial and Commercial Applications of Smart Structures Technologies. A. McGowan, ed. Proc. SPIE 4698, pp. 254-270 (2002) 